\title{
RTEL1 tagging SNPs and haplotypes were associated with glioma development
}

\author{
Gang $\mathrm{Li}^{1 \dagger}$, Tianbo Jin ${ }^{2 \dagger}$, Hongjuan Liang ${ }^{1}$, Zhiguo Zhang ${ }^{1}$, Shiming He${ }^{1}$, Yanyang $\mathrm{Tu}^{3}$, Haixia Yang ${ }^{1}$, \\ Tingting Geng ${ }^{4}$, Guangbin Cui ${ }^{5}$, Chao Chen ${ }^{2^{*}}$ and Guodong Gao ${ }^{1^{*}}$
}

\begin{abstract}
As glioma ranks as the first most prevalent solid tumors in primary central nervous system, certain singlenucleotide polymorphisms (SNPs) may be related to increased glioma risk, and have implications in carcinogenesis. The present case-control study was carried out to elucidate how common variants contribute to glioma susceptibility. Ten candidate tagging SNPs (tSNPs) were selected from seven genes whose polymorphisms have been proven by classical literatures and reliable databases to be tended to relate with gliomas, and with the minor allele frequency (MAF) > 5\% in the HapMap Asian population. The selected tSNPs were genotyped in 629 glioma patients and 645 controls from a Han Chinese population using the multiplexed SNP MassEXTEND assay calibrated. Two significant TSNPS in RTEL1 gene were observed to be associated with glioma risk (rs6010620, $P=0.0016$, OR: 1.32, 95\% Cl: 1.11-1.56; rs2297440, $P=0.001$, OR: $1.33,95 \%$ Cl: 1.12-1.58) by $X^{2}$ test. It was identified the genotype "GG" of rs6010620 acted as the protective genotype for glioma (OR, 0.46; $95 \% \mathrm{Cl}, 0.31-0.7 ; P=0.0002)$, while the genotype "CC" of rs2297440 as the protective genotype in glioma $(\mathrm{OR}, 0.47 ; 95 \% \mathrm{Cl}, 0.31-0.71 ; P=0.0003)$. Furthermore, haplotype "GCT" in RTEL1 gene was found to be associated with risk of glioma (OR, 0.7; $95 \% \mathrm{Cl}$, 0.57-0.86; Fisher's $P=0.0005$; Pearson's $P=0.0005$ ), and haplotype "ATT" was detected to be associated with risk of glioma (OR, 1.32; $95 \% \mathrm{Cl}, 1.12-1.57$; Fisher's $P=0.0013$; Pearson's $P=0.0013$ ). Two single variants, the genotypes of "GG" of rs6010620 and "CC" of rs2297440 (rs6010620 and rs2297440) in the RTEL1 gene, together with two haplotypes of GCT and AT, were identified to be associated with glioma development. And it might be used to evaluate the glioma development risks to screen the above RTEL1 tagging SNPs and haplotypes.
\end{abstract}

Virtual slides: The virtual slides for this article can be found here: http://www.diagnosticpathology.diagnomx.eu/vs/ 1993021136961998

Keywords: Tagging single nucleotide polymorphism (tSNP), Glioma, RTEL1, Haplotype, Case - control studies

\section{Introduction}

The overall incidence of brain tumors for benign and malignant tumors combined is 18.71 per 100,000 person-years; 11.52 per 100,000 person-years for benign tumors and 7.19 per 100,000 person-years for malignant tumors [1]. Though the age- standardized incidence recently reported varied greatly than ever, non-malignant tumours still accounted for $66 \%$ of all newly diagnosed primary brain tumours with the age-standardized

\footnotetext{
*Correspondence: chenchao@163.com; gguodong@fmmu.edu.cn 'Equal contributors

${ }^{2}$ National Engineering Research Center for Miniaturized Detection Systems, School of Life Sciences, Northwest University, Xi'an 710069, China

'Department of Neurosurgery, Tangdu hospital, the Fourth Military Medical University, Xi'an 710038, China

Full list of author information is available at the end of the article
}

incidence rate of 3.57 per 100,000 person-years, while malignant tumours incidence rate was 1.82 per 100,000 person-years (crude incidence rates were 3.69 and 1.92 per 100,000 respectively) [2]. Gliomas, most aggressive malignant brain tumours (astrocytic, oligodendroglial, oligoastrocytic and ependymal origin), represent $20.8 \%$ of all brain tumours [2], and account for almost $80 \%$ of primary malignant brain tumors, usually resulting in poor survival compared to other types of brain tumors [3].

Current evidence suggests that inherited risks play a significant role in glioma susceptibility, as with other cancers, and a majority of the inherited risk is due to the co-inheritance of multiple low-risk variants. These variants are commonly seen gene variants and hence can be identified through association studies [4]. The

\section{Biomed Central}


epidemiology of glioma has focused on identifying factors that can be modified to prevent this disease [5-7]. Recently studies of genetic risk factors for brain tumors have expanded to genome-wide association studies, and have focused on identifying germline polymorphisms associated with the risk of glioma as well as using molecular markers to classify glial tumors in more homogenous groups [6,7].

A research group from the University of Texas M.D. Anderson Cancer Center conducted a meta-analysis of two genome-wide association studies (GWAS) by genotyping $550 \mathrm{~K}$ tagging single nucleotide polymorphisms (tSNPs) in a total of 1,878 cases and 3,670 controls, with validation in three additional independent series totaling 2,545 cases and 2,953 controls. They identified five risk loci for glioma including rs6010620 intronic to RTEL1 gene $\left(P=2.52 \times 10^{-12}\right)$ to be associated with glioma risk [6]. Another study in Chinese also identified rs60106203 for glioma risk $\left(P=2.793 \times 10^{-6}\right)$, and the locus also associated with glioblastoma risk $\left(P=3.573 \times 10^{-7}\right)$ [8]. The subsequent study found that rs6010620 was statistically significantly associated with glioma risk in US female population [9]. Recently, a new independent GWAS of glioma using 1,856 cases and 4, 955 controls has found evidence of strong replication for three of the seven previously reported associations at 20q13.33 (RTEL), 5p15.33 (TERT), and 9p21.3 (CDKN2BAS), and consistent association signals for the remaining four at $7 \mathrm{p} 11.2$ (EGFR both loci), 8q24.21 (CCDC26) and 11q23.3 (PHLDB1) [7]. These data tend to show that common susceptibility alleles contribute to the risk of developing glioma and provide insight into disease causation of this primary brain tumor.

As the Chinese Han population is by far the population with the largest number in the world, we comprehensively analysized in this study the associations between RTEL1 genotypes and haplotypes with glioma risk, to uncover how germ-line genetic variants of the RTEL1 gene play a complex role in the development of glioma, to offer important insights into the etiology of glioma in the certain Chinese Han population.

\section{Patients and methods Study population}

A total of 629 patients with glioma, includes welldifferentiated pilocytic astrocytoma [World Health Organization (WHO) grade I], low grade ependymomas [WHO grade II], low grade astrocytomas [WHO grade II], low grade oligodendrogliomas [WHO grade II], anaplastic astrocytomas [WHO grade III] and glioblastoma multiforme (GBM) [WHO grade IV] [10], between November 2008 and December 2012 were recruited into an ongoing molecular epidemiological study at the Department of Neurosurgery of the Tangdu Hospital affiliated with The Fourth
Military Medical University (FMMU) in Xi'an city, China. All glioma cases had no previous history of other cancers, or prior chemotherapy or radiotherapy. There were no age, sex, or disease stage restrictions for case recruitment. There were no age, sex, or disease stage restrictions for case recruitment. All the slides of glioma tissues were reevaluated according to WHO classifications [10] by two pathologists, with differences resolved by careful discussion. The median age was 43 years (age range, $1-81$ ). The clinicopathological features and the treatment strategies of all the patients were indicated in Table 1.

A total of 645 healthy unrelated individuals as the controls between June 2010 and August 2012 were recruited from the medical examination center at Tangdu Hospital, for genetic association research of human complex diseases, such as lung cancer, stomach cancer, and glioma. The median age was 45 years (age range 4-83). The detailed recruitment and exclusion criteria were used. Generally, subjects with chronic diseases and conditions involving vital organs (heart, lung, liver, kidney, and brain) and severe endocrinological, metabolic, and nutritional diseases were excluded from this study. The purpose of the above exclusion procedures was to minimize the known environmental and therapeutic factors that influence the variation of human complex diseases.

In our study population, all analyses were restricted to the Han Chinese living in Xi'an city and its surrounding areas. A written informed consent was obtained from all the subjects or their custodians, and we collected all the blood samples from the controls and the patients before chemotherapy or radiotherapy. All specimens were handled and made anonymous according to the ethical and legal standards. The protocol was approved by the Medical Ethics Committee of the Fourth Military Medical University.

\section{Demographic and clinical data}

Demographic and personal data were collected through an in-person interview using a standardized epidemiological questionnaire, including age, sex, ethnicity, residential region, smoking status, alcohol use, education status, and family history of cancer. For patients, detailed clinical information was collected through a medical chart review or consultation with treating physicians. Plasma carcinoembryonic antigen and alphafetoprotein were tested in control subjects to make sure they did not have any cancers.

\section{Blood samples collection, DNA extraction and SNP selection and genotyping}

Peripheral blood was taken from the 629 glioma patients and 645 apparently healthy individuals, and from the elbow vein or the head superficial vein, and treated 
Table 1 Clinicopathological features of 629 glioma patients

\begin{tabular}{|c|c|c|c|c|c|c|}
\hline \multirow[t]{2}{*}{ Clinicopathological features } & \multirow{2}{*}{$\begin{array}{l}\text { WHO I } \\
\text { Pilocytic } \\
\text { astrocytoma }\end{array}$} & \multicolumn{3}{|l|}{ WHO II } & \multirow{2}{*}{$\begin{array}{l}\text { WHO III } \\
\text { Anaplastic } \\
\text { astrocytoma }\end{array}$} & \multirow{2}{*}{$\begin{array}{l}\text { WHO IV } \\
\text { Glioblastoma } \\
\text { multiforme }\end{array}$} \\
\hline & & Astrocytoma & Oligodendroglioma & Ependymoma & & \\
\hline \multicolumn{7}{|l|}{ Case Number } \\
\hline Total & 20 & 433 & 24 & 34 & 81 & 37 \\
\hline Male & 11 & 241 & 13 & 17 & 39 & 21 \\
\hline Female & 9 & 192 & 11 & 17 & 42 & 16 \\
\hline \multicolumn{7}{|l|}{ Mean age (Age range) (ys) } \\
\hline Total & $12(2-51)$ & $42(1-81)$ & $46(17-76)$ & $29(1-71)$ & $50(2-81)$ & $47(6-70)$ \\
\hline Male & $13(3-35)$ & $41(1-81)$ & $53(35-76)$ & $34(5-60)$ & $50(2-73)$ & $48(17-70)$ \\
\hline Female & $9(2-51)$ & $42(2-79)$ & $41(17-55)$ & $20(1-71)$ & $52(10-81)$ & $44(6-67)$ \\
\hline \multicolumn{7}{|l|}{ KPS } \\
\hline$\geq 70$ & 19 & 423 & 24 & 33 & 79 & 35 \\
\hline$<70$ & 1 & 10 & 0 & 1 & 2 & 2 \\
\hline \multicolumn{7}{|l|}{ Surgery } \\
\hline Gross total resection & 20 & 412 & 22 & 32 & 76 & 36 \\
\hline Partial resection & 0 & 10 & 2 & 1 & 3 & 1 \\
\hline Biopsy & 0 & 11 & 0 & 1 & 2 & 0 \\
\hline \multicolumn{7}{|l|}{ Adjuvant treatment } \\
\hline Radiotherapy & 0 & 280 & 18 & 17 & 4 & 0 \\
\hline Chemotherapy & 0 & 55 & 1 & 1 & 0 & 0 \\
\hline $\begin{array}{l}\text { Radiotherapy and Chemotherapy } \\
\text { combination }\end{array}$ & 0 & 98 & 5 & 16 & 77 & 37 \\
\hline
\end{tabular}

KPS Karnofsky performance score.

immediately with an anticoagulant containing sodium citrate $(22 \mathrm{~g} / \mathrm{L})$ and sodium chloride $(8.5 \mathrm{~g} / \mathrm{L})$. The blood samples were then stored at $-70^{\circ} \mathrm{C}$ before use. Genomic DNA was isolated from the samples by using an extraction kit (GoldMag, China). DNA concentration and purity were determined by an ultraviolet spectrophotometer (Eppendorf, Hamburg, Germany).

Candidate tSNPs in the seven genes were selected from previously published polymorphisms associated with glioma.
Validated tSNPs were selected with a minor allele frequency $(\mathrm{MAF})>5 \%$ in the HapMap Asian population. A total of 10 tSNPs were selected for further genotyping. Genomic DNA was extracted from whole blood using the phenolchloroform extraction method. DNA concentration was measured by spectrometry (DU530 UV/VIS spectrophotometer, Beckman Instruments, Fullerton, CA, USA). A multiplexed SNP MassEXTEND assay was designed with the Sequenom MassARRAY Assay Design 3.0 Software [11].

Table 2 Primers used in the study

\begin{tabular}{|c|c|c|c|c|}
\hline SNP_ID & & 1st-PCR primer sequences & 2nd-PCR primer sequences & UEP sequences \\
\hline rs2992 & $\mathrm{G} / \mathrm{A}$ & ACGTTGGATGTCAAGTATCTGCTCTGTGGG & ACGTTGGATGACTGGGTGCATCCTGAGAG & cgatAGCAGGGGTGACGTATGTAGAA \\
\hline rs12022378 & $\mathrm{C} / \mathrm{T}$ & ACGTTGGATGAGATGCCTGGACCAGCTCT & ACGTTGGATGCAATTACAGCCCACCTCTTG & cctaaAGCCCACCTCTTGCATCGT \\
\hline rs12917 & $\mathrm{T} / \mathrm{C}$ & ACGTTGGATGCGAGGCTATCGAAGAGTTCC & ACGTTGGATGAGATGGCTTAGTTACCGACC & gctaGAAAACGGGATGGTGAA \\
\hline rs12645561 & $\mathrm{T} / \mathrm{C}$ & ACGTTGGATGTTACAGTTCTCTTTCACAG & ACGTTGGATGGCAGAGCCTAGTTTCATGAC & TTGCTCATTACTGTAAGAAATAATAC \\
\hline rs7003908 & $\mathrm{C} / \mathrm{A}$ & ACGTTGGATGGGGGAGAAAATATTCCTGTT & ACGTTGGATGTCCTACCTCACGAACTCAGC & AGCAATTGCCTAAGAGTC \\
\hline rs6010620 & $\mathrm{G} / \mathrm{A}$ & ACGTTGGATGGCCTGTTTTCCCTIITTGAG & ACGTTGGATGCCTCTCAACATCTCAGCAAC & tGATCATGCAAAGCAGG \\
\hline rs2297440 & $\mathrm{T} / \mathrm{C}$ & ACGTTGGATGACGAGGTCTGGTGGCACAT & ACGTTGGATGCACTGTCCTITGCGTCCTC & gtTCCTCCCTCACCAGC \\
\hline rs4809324 & $\mathrm{C} / \mathrm{T}$ & ACGTTGGATGGAGAAGTCAAGTGACATCAG & ACGTTGGATGAGCCGGTGCACAGATTCCAA & gagggCAAGGGCCTGGAATCTGT \\
\hline rs3770502 & $A / G$ & ACGTTGGATGCTATATGGGTGCAGATGCAG & ACGTTGGATGACAGGCGTGAACCACTGTA & ACCCGGCCCCTCCAC \\
\hline rs9288516 & $\mathrm{A} / \mathrm{T}$ & ACGTTGGATGACAGGCCAAGGGCAATAATC & ACGTTGGATGGCTTCCTAAGATTTCCTATTC & CATTTCAAAAGAAATGGAGAAT \\
\hline
\end{tabular}

UEP Unextended mini-sequencing primer. 
Table 3 Tagging SNPs information that were examined

\begin{tabular}{|c|c|c|c|c|c|c|c|c|c|c|c|c|}
\hline \multirow[t]{2}{*}{ SNP No. } & \multirow[t]{2}{*}{ Gene } & \multirow[t]{2}{*}{ chr } & \multirow[t]{2}{*}{ Position } & \multirow[t]{2}{*}{ MA } & \multirow{2}{*}{$\begin{array}{l}\text { MAF } \\
\text { (CHB) }\end{array}$} & \multicolumn{2}{|c|}{ MAF } & \multirow{2}{*}{$\begin{array}{c}\text { HWE } \\
P\end{array}$} & \multirow[t]{2}{*}{$P$} & \multirow[t]{2}{*}{ OR $(95 \% \mathrm{Cl})$} & \multirow{2}{*}{$\begin{array}{c}P \\
\text { adj. }\end{array}$} & \multirow{2}{*}{$\begin{array}{c}\text { Genotype } \\
\text { rate }\end{array}$} \\
\hline & & & & & & Case & $\overline{\text { Control }}$ & & & & & \\
\hline rs12022378 & $A P 4 B 1$ & chr1 & 114448389 & C & 0.411 & 0.360 & 0.393 & 0.4943 & 0.0889 & $1.15(0.98-1.35)$ & 0.889 & 99.34 \\
\hline rs12917 & MGMT & chr10 & 131506283 & $\mathrm{~T}$ & 0.31 & 0.105 & 0.082 & 0.2082 & 0.0497 & $0.76(0.58-1)$ & 0.497 & 99.67 \\
\hline rs12645561 & NEIL3 & chr4 & 178260872 & $\mathrm{~T}$ & 0.114 & 0.275 & 0.268 & 0.1388 & 0.6903 & $0.97(0.81-1.15)$ & 6.903 & 99.34 \\
\hline rs7003908 & PRKDC & chr8 & 48770702 & C & 0.283 & 0.236 & 0.209 & 0.1246 & 0.1074 & $0.86(0.71-1.03)$ & 1.074 & 99.83 \\
\hline rs6010620 & RTEL 1 & chr20 & 62309839 & G & 0.393 & 0.269 & 0.327 & 0.194 & 0.0016 & $1.32(1.11-1.56)$ & 0.016 & 99.83 \\
\hline rs2297440 & RTEL1 & chr20 & 62312299 & C & 0.226 & 0.266 & 0.325 & 0.3127 & 0.001 & $1.33(1.12-1.58)$ & 0.01 & 100 \\
\hline rs4809324 & RTEL 1 & chr20 & 62318220 & C & 0.12 & 0.114 & 0.120 & 0.6994 & 0.6328 & $1.06(0.83-1.35)$ & 6.328 & 99.67 \\
\hline rs2992 & UBXN6 & chr19 & 4443046 & A & 0.295 & 0.436 & 0.433 & 0.4229 & 0.8701 & $0.99(0.84-1.16)$ & 8.701 & 99.67 \\
\hline rs3770502 & XRCC5 & chr2 & 217045059 & A & 0.208 & 0.148 & 0.160 & 0.7558 & 0.4221 & $1.09(0.88-1.36)$ & 4.221 & 99.83 \\
\hline rs9288516 & XRCC5 & chr2 & 217053264 & A & 0.489 & 0.480 & 0.450 & 0.4774 & 0.1288 & $0.89(0.76-1.04)$ & 1.288 & 99.67 \\
\hline
\end{tabular}

SNP genotyping was performed using the Sequenom MassARRAY RS1000 with standard protocol recommended by the manufacturer [11]. Data management and analyses were performed using Sequenom Typer 4.0 software as previously described $[11,12]$.

\section{Statistical analysis}

Statistical analyses were performed using Microsoft Excel and SPSS 16.0 statistical packages (SPSS, Chicago, IL). All $P$ values in this study were two-sided. A $P \leq 0.05$ was considered the threshold of statistical significance. Genotypic frequencies in control subjects for each tSNP were tested for departure from Hardy-Weinberg equilibrium (HWE) using an exact test. Genotype frequencies and allele frequencies of glioma patients and control subjects were compared using the $\chi^{2}$ test [13]. Odds ratios (ORs) and 95\% confidence intervals (CIs) were calculated by unconditional logistic regression analysis with adjustment for age and sex [14]. We did not divide subjects into subgroups because of limited sample size. The possibility of sex differences as a source of population sub-structure was evaluated by a genotype test for each tSNP in male and female controls, and the number of significant results at the $5 \%$ level was compared with the number expected by the $x^{2}$ test. We did not detect population stratification because all participants' ethnicity was Han Chinese. The four genetic models (dominant, recessive, additive and genotypic) were applied by PLINK software (http://pngu. mgh. harvard.edu/purcell/ plink/) to assess the association of single tSNP with the risk of glioma. ORs and 95\% CIs were calculated by unconditional logistic regression analysis adjusted for age and sex $[14,15]$.

We used the Haploview software package (version 4.2) and SHEsis software platform (http://www.nhgg.org/analysis/) for analyses of linkage disequilibrium, haplotype construction, and genetic association at polymorphism loci $[16,17]$ ORs and 95\% CIs were calculated by unconditional logistic regression analysis with adjustment for age and gender [14]. Additionally, the likelihood ratio test was performed to determine the genotype frequencies among various grade groups. The $\chi 2$ test was also used for comparison of categorical variables. A $P$ value of $<0.05$ (two-tailed) was considered statistically significant.

\section{Results}

A total of 629 cases (310 male, 319 female; median age at diagnosis $41 \pm 18 \mathrm{yrs}$ ) and 645 controls (329 male, 316 female; median age at $45 \pm 12$ yrs) were included in the current study. Basic characteristics of the cases are listed in Table 1 including gender, age, and pathology. As listed in Table 2, a multiplexed SNP MassEXTEND assay was designed with Sequenom MassARRAY Assay Design 3.0 Software. Ten SNPs of seven candidate genes were genotyped in glioma patients and the control group, the average tSNPs call rate was $99.6 \%$ in cases and controls, and all of the tested tSNPs are in Hardy-Weinberg equilibrium (HWE) in the control population of this study (Table 3). Two significant tSNPs in the RTEL1 gene were observed to be associated with glioma risk at a 5\% level (rs6010620, $P=0.0016$, OR: 1.32, 95\% CI: 1.11-1.56; rs2297440, $P=0.001$, OR: $1.33,95 \%$ CI: $1.12-1.58)$ by $\chi^{2}$ test.

Association results between tSNP genotypes and the risk of glioma were listed in Table 4. We found that the genotype "GG" of rs6010620 as the protective genotype for glioma (OR, 0.46; 95\% CI, 0.31-0.7; $P=0.0002)$, and the genotype "CC" of rs2297440 as the protective genotype in glioma (OR, 0.47; 95\% CI, 0.31-0.71; $P=0.0003$ ).

We assumed that the minor allele of each tSNP was a risk allele compared to the wild type allele. Four tSNPs were detected to be associated with glioma by model association analyses including rs6010620 and rs2297440 in the RTEL1 gene, rs12022378 in the DCLRE1B gene, and rs12917 in the MGMT gene (Table 5). We observed two 
Table 4 Association between tSNP genotypes and the risk of glioma

\begin{tabular}{|c|c|c|c|c|c|}
\hline \multirow[t]{2}{*}{ SNP ID } & \multirow[t]{2}{*}{ Genotype } & \multicolumn{2}{|c|}{ No. (frequency) } & \multicolumn{2}{|c|}{ Logistic regression } \\
\hline & & Case & Control & OR $(95 \% \mathrm{Cl})$ & $P$ value \\
\hline rs12022378 & $C C$ & $114(18.2)$ & $87(13.6)$ & $0.71(0.51-0.99)$ & 0.0418 \\
\hline rs12022378 & CT & $265(42.2)$ & $288(44.9)$ & $1.01(0.8-1.29)$ & 0.9127 \\
\hline rs12022378 & $\pi$ & 249(39.6) & $267(41.6)$ & 1 (referent) & \\
\hline rs12917 & $\pi$ & $6(1)$ & 10(1.6) & $1.7(0.61-4.72)$ & 0.3011 \\
\hline rs12917 & $\mathrm{TC}$ & $91(14.5)$ & $115(17.9)$ & $1.29(0.96-1.74)$ & 0.0956 \\
\hline rs12917 & CC & 530(84.5) & $519(80.6)$ & 1 (referent) & \\
\hline rs12645561 & $\pi$ & $43(6.8)$ & $56(8.7)$ & $1.26(0.83-1.93)$ & 0.2784 \\
\hline rs12645561 & $\mathrm{TC}$ & $251(40)$ & $241(37.6)$ & $0.93(0.74-1.18)$ & 0.5537 \\
\hline rs12645561 r r r & CC & $334(53.2)$ & $344(53.7)$ & 1 (referent) & \\
\hline rs7003908 & CC & $31(4.9)$ & $43(6.7)$ & $1.44(0.89-2.33)$ & 0.1387 \\
\hline r57003908 & CA & $201(32)$ & $217(33.7)$ & $1.12(0.88-1.42)$ & 0.3536 \\
\hline rs7003908 & AA & $397(63.1)$ & $383(59.6)$ & 1 (referent) & \\
\hline rs6010620 & GG & 75(11.9) & $40(6.2)$ & $0.46(0.31-0.7)$ & 0.0002 \\
\hline rs6010620 & GA & $261(41.5)$ & $267(41.5)$ & $0.89(0.71-1.12)$ & 0.3212 \\
\hline rs6010620 & AA & 293(46.6) & $337(52.3)$ & 1 (referent) & \\
\hline rs2297440 & CC & 73(11.6) & $40(6.2)$ & $0.47(0.31-0.71)$ & 0.0003 \\
\hline rs2297440 & CT & 263(41.8) & $263(40.8)$ & $0.86(0.68-1.08)$ & 0.1902 \\
\hline rs2297440 & $\pi$ & 293(46.6) & $342(53)$ & 1 (referent) & \\
\hline rs4809324 & CC & $11(1.8)$ & $7(1.1)$ & $0.62(0.24-1.6)$ & 0.3162 \\
\hline rs4809324 & $\mathrm{CT}$ & $129(20.5)$ & $133(20.7)$ & $1(0.76-1.31)$ & 0.9901 \\
\hline rs4809324 & $\pi$ & $488(77.7)$ & $504(78.3)$ & 1(referent) & \\
\hline rs2992 & AA & $126(20.1)$ & $117(18.2)$ & $0.98(0.71-1.35)$ & 0.9003 \\
\hline rs2992 & AG & $292(46.5)$ & $328(50.9)$ & $1.19(0.92-1.52)$ & 0.182 \\
\hline rs2992 & GG & 210(33.4) & 199(30.9) & 1 (referent) & \\
\hline rs3770502 r r r & AA & $12(1.9)$ & $15(2.3)$ & $1.18(0.54-2.54)$ & 0.6809 \\
\hline rs3770502 r r r & AG & $177(28.1)$ & $161(25)$ & $0.86(0.67-1.1)$ & 0.2198 \\
\hline rs3770502 r r r & GG & $440(70)$ & $468(72.7)$ & 1 (referent) & \\
\hline s9288516 & $\mathrm{AA}$ & $128(20.4)$ & $153(23.8)$ & $1.28(0.93-1.74)$ & 0.1249 \\
\hline 9288516 & AT & $308(49.1)$ & $312(48.4)$ & $1.08(0.84-1.4)$ & 0.553 \\
\hline 9288516 & $\pi$ & $191(30.5)$ & $179(27.8)$ & 1 (referent) & \\
\hline
\end{tabular}

OR odd ratio, $\mathrm{Cl}$ confidence interval.

tSNPs in RTEL1 gene to be associated with the risk of glioma by recessive model (rs6010620, OR, 2.09; 95\% CI, 1.39-3.13; $P=0.0004$, and rs2297440, OR, 2.02; 95\% CI, $1.35-3.04 ; \quad P=0.0007)$. Rs12022378 in the DCLRE1B gene was also found by recessive model associated with glioma risk (OR, 1.42; 95\% CI, 1.05-1.93; $P=0.0246$ ). Rs6010620 and rs2297440 were also detected by Dominant Model with increased risk of glioma (rs6010620, OR, 1.26; 95\% CI, 1.01-1.57; $P=0.041$, and rs2297440, OR, 1.3; 95\% CI, 1.04-1.62; $P=0.022$ ). Another SNP, rs 12917 in the MGMT gene, was associated with decreased glioma risk by recessive model analysis (OR, 0.73; 95\% CI, 0.54-0.98; $P=0.036)$. Rs6010620, rs2297440 and rs12917 were also found to be associated with glioma risk by additive model analyses (rs6010620, OR, 1.32; 95\% CI, 1.11-1.57; $P=0.0015$, rs2297440, OR, 1.34; 95\% CI, $1.12-1.59 ; P=0.001$ and rs12917, OR, 0.75; 95\% CI, $0.58-0.99 ; P=0.038$ ). Genotypic model analyses results shown that three tSNPs were significant to be associated with glioma risk (rs6010620, OR, 1.48; 95\% CI, 1. 2-1.83; $P=0.0002$, rs2297440, OR, 1.47; 95\% CI, 1.19$1.82 ; P=0.000$, and $\mathrm{rs} 12022378$, OR, $1.19 ; 95 \% \mathrm{CI}, 1.0-$ $1.4 ; P=0.043)$.

Only one block was detected in RTEL1 gene by haplotype analysis. Global result for the block was: total case $=1286$, total control $=1256$, global $\chi^{2}=13.0855$ while $\mathrm{df}=2$, Fisher's $P$ value $=0.0015$, and Pearson's $P$ value $=0.0014$. The results of the association between the RTEL1 gene haplotypes and the risk of glioma are listed in Table 6. Haplotype "GCT" in RTEL1 gene was found to be associated with risk of glioma (OR, 0.7; 95\% CI, 0.57-0.86; Fisher's $P=0.0005$; Pearson's $P=0.0005$ ). Haplotype "ATT" was found to be associated with risk of glioma (OR, 1.32; 95\% CI, 1.12-1.57; Fisher's $P=0.0013$; Pearson's $P=0.0013$ ).

Furthermore, the associations between different clinicopatholiogical features and genotype frequency of GG in rs6010620, together with CC in rs2297440 in glioma patients $(n=75,73$, respectively) were analyzed. GG frequency in various grade goups were determined, being $16.0 \%$ (12/75), $46.7 \%$ (35/75), $16.0 \%$ (12/75), and $21.3 \%$ (16/75), respectively, in grade I,II,III, and IV group $(P>0.05)$, and $\mathrm{CC}$ frequency in various grade goups were determined as $14.7 \%$ (11/73), 56.2\% (35/73), 17.8\% (13/73), and $19.2 \%$ (14/73), respectively, in grade I, II, III, and IV group $(\mathrm{P}>0.05)$ (Table 7). No significant association was found between genotype frequency of GG or $\mathrm{CC}$, and other parameters including WHO grading, gender, age at diagnosis, or Karnofsky performance score (KPS).

\section{Discussion}

As known, biomarker detection and screening is an emerging field for oncology [18-23]. Especially for gliomas considerable progresses have been made in identifying, characterizing, and attempting to apply molecular markers, e.g. in the previous study, we initially found the increased expression of miR-372 in glioma tissues was significantly correlated with advanced tumor progression and aggressive clinicopathological features [24]. And subsequently a series of have determined the associations between lots of SNPs in $A B C B 1, N R$ 1/2, VEGFR 3, etc. and therapy outcome [25-27].

In this case-control study in Han Chinese population, we found two susceptibility tSNPs in RTEL1 gene that were associated with increased risk of glioma (rs6010620 and rs2297440). The genotype "GG" of rs6010620 was the protective genotype for glioma, and the genotype "CC" of 
Table 5 Association between tSNPs and the risk of glioma and their heterozygote and homozygote odds ratios, per allele odds ratios and confidence intervals

\begin{tabular}{|c|c|c|c|c|c|c|c|c|c|c|c|c|c|c|c|c|}
\hline \multirow{3}{*}{$\begin{array}{l}\text { SNP No. } \\
\text { rs12022378 }\end{array}$} & \multicolumn{4}{|c|}{ Dominant model } & \multicolumn{4}{|c|}{ Recessive model } & \multicolumn{4}{|c|}{ Additive model } & \multicolumn{4}{|c|}{ Genotypic model } \\
\hline & \multirow{2}{*}{$\frac{\text { OR }}{1.08}$} & \multicolumn{2}{|c|}{$95 \% \mathrm{Cl}$} & \multirow{2}{*}{$\frac{\boldsymbol{P} \text {-value }}{0.4966}$} & \multirow{2}{*}{$\frac{\text { OR }}{1.42}$} & \multicolumn{2}{|c|}{$95 \% \mathrm{Cl}$} & \multirow{2}{*}{$\frac{\boldsymbol{P} \text {-value }}{0.0246}$} & \multirow{2}{*}{$\frac{\text { OR }}{1.14}$} & \multicolumn{2}{|c|}{$95 \% \mathrm{Cl}$} & \multirow{2}{*}{$\frac{P \text { value }}{0.1031}$} & \multirow{2}{*}{$\begin{array}{l}\text { OR } \\
1.19\end{array}$} & \multicolumn{2}{|c|}{$95 \% \mathrm{Cl}$} & \multirow{2}{*}{$\frac{P \text { value }}{0.0426}$} \\
\hline & & 0.86 & 1.36 & & & 1.05 & 1.93 & & & 0.97 & 1.33 & & & 1.01 & 1.40 & \\
\hline rs2992 & 0.90 & 0.71 & 1.14 & 0.3963 & 1.14 & 0.86 & 1.51 & 0.3714 & 0.99 & 0.85 & 1.16 & 0.9496 & 1.02 & 0.87 & 1.19 & 0.8340 \\
\hline rs12917 & 0.73 & 0.54 & 0.98 & 0.0359 & 0.70 & 0.25 & 1.94 & 0.4882 & 0.75 & 0.58 & 0.98 & 0.0383 & 0.81 & 0.49 & 1.36 & 0.4362 \\
\hline rs12645561 & 1.02 & 0.82 & 1.28 & 0.8315 & 0.74 & 0.49 & 1.12 & 0.1499 & 0.96 & 0.81 & 1.15 & 0.6584 & 0.87 & 0.70 & 1.08 & 0.2142 \\
\hline rs7003908 & 0.87 & 0.69 & 1.10 & 0.2372 & 0.74 & 0.46 & 1.19 & 0.2102 & 0.87 & 0.73 & 1.05 & 0.1492 & 0.84 & 0.66 & 1.08 & 0.1684 \\
\hline rs6010620 & 1.26 & 1.01 & 1.57 & 0.0410 & 2.09 & 1.39 & 3.13 & 0.0004 & 1.32 & 1.11 & 1.57 & 0.0015 & 1.48 & 1.20 & 1.83 & 0.0002 \\
\hline rs2297440 & 1.30 & 1.04 & 1.62 & 0.0221 & 2.02 & 1.35 & 3.04 & 0.0007 & 1.34 & 1.12 & 1.59 & 0.0010 & 1.47 & 1.19 & 1.82 & 0.0003 \\
\hline rs4809324 & 1.03 & 0.79 & 1.34 & 0.8386 & 1.76 & 0.67 & 4.60 & 0.2490 & 1.06 & 0.83 & 1.36 & 0.6257 & 1.33 & 0.82 & 2.14 & 0.2513 \\
\hline rs3770502 & 1.16 & 0.91 & 1.48 & 0.2314 & 0.79 & 0.37 & 1.72 & 0.5557 & 1.11 & 0.89 & 1.38 & 0.3668 & 0.91 & 0.62 & 1.34 & 0.6410 \\
\hline rs9288516 & 0.90 & 0.70 & 1.14 & 0.3803 & 0.84 & 0.64 & 1.10 & 0.1972 & 0.90 & 0.77 & 1.05 & 0.1896 & 0.90 & 0.77 & 1.05 & 0.1789 \\
\hline
\end{tabular}

OR odd ratio, $\mathrm{Cl}$ confidence interval.

rs2297440 was the protective genotype in glioma. We also observed in the RTEL1 gene a haplotype "GCT" that was associated with a decreased the risk and a haplotype of "ATT" with an increased risk of developing glioma.

As described initially, however, we failed to determine the associations between genotype frequency of GG or $\mathrm{CC}$, and other parameters including WHO grading, gender, age at diagnosis, or KPS status. Additionally, we also tried to elucidate the relationship of genotype frequency of GG or CC, with overall surviaval (OS) in the correlated patients. During the follow-up period, only 11 of the patients with genotype of GG or CC had died [6 (8\%) from the 75 patients with genotype GG, and $5(6.8 \%)$ from the 73 patients with genotype CC], and most of the patients are alive and are being traced continuously.

Albeit the correlated survival data in the present study are still accumulating, our findings in this study have provided new evidence for the association between common SNPs (or haplotypes) and the risk of glioma in the Chinese Han population, suggesting an important determinant of glioma development by RTEL1 gene. RTEL1 gene locates in 20q13.3 with the length of $40.889 \mathrm{~kb}$, including 40 exons. Known functions of RTEL1 include nucleic acid binding, ATP-dependent DNA helicase activity, DNA repair, apoptosis and anti-apoptosis, and so on. Previous study proposed that RTEL1 maintains genomic stability by suppressing homologous recombination
$[28,29]$, and implements the second level of meiotic crossover control by promoting non-crossovers [30,31]. A recent review point out that RTEL1 was an essential helicase for telomere maintenance and the regulation of homologous recombination [32,33]. RTEL1 didn't involve any KEGG pathway (http://www. genome.jp/kegg/) so far. The frequencies of rs6010620 risk genotypes were highly correlated with high-grade disease $(P<0.001)$, indicating that genetic variations at the locus has subtypespecific effects on the risk of developing glioma [34]. RTEL1 gene was over expressed in human gastrointestinal tract tumors [35]. Polymorphism in the RTEL1 gene was associated with glioblastoma survival [36].

Some limitations are inherent in this case-control study and must be noted here. Glioma patients were not sub-grouped by age or gender, and gender-specific significant variants were not tested. We selected tSNPs with frequencies higher than 5\% in HapMap Asian populations to affirm the statistical power was large enough for analyzing data. We also designed a haplotype-based study to ensure sufficiently high power to detect the risk of glioma associated with candidate tSNPs. Another potential concern was population admixture, which is a known confounding factor for association analysis and may also result in inflated type-I error (false positive). In this study, glioma patients and controls were used in the same hospital to avoid the possibility that one may have a more pronounced selection bias. However, this bias is

Table 6 Haplotype frequencies of RTEL1 gene and association with risk of glioma in cases and controls

\begin{tabular}{ccccccrr}
\hline Haplotype & Freq(case) & Freq(ctrl) & Chi2 & Fisher's $\boldsymbol{P}$ & Pearson's $\boldsymbol{P}$ & Odds ratio & {$[\mathbf{9 5 \%}$ Cl] } \\
\hline A T T & 0.7294 & 0.6728 & 10.3722 & 0.0013 & 0.0013 & 1.32 & {$[1.12,1.57]$} \\
G C C & 0.1135 & 0.1194 & 0.1959 & 0.6581 & 0.6581 & 0.95 & {$[0.74,1.21]$} \\
G C T & 0.1524 & 0.2054 & 11.9905 & 0.0005 & 0.0005 & 0.70 & {$[0.57,0.86]$} \\
\hline
\end{tabular}

Note: Loci chosen for hap-analysis: rs6010620, rs2297440 and rs4809324 (RTEL1); OR odd ratio, Cl confidence interval. 
Table 7 Associations between different clinicopatholiogical features and genotype frequency of GG in rs6010620, and CC in rs2297440 of RTEL1 gene in glioma patients ( $n=75,73$, respectively)

\begin{tabular}{ccccc}
\hline $\begin{array}{c}\text { Clinicopatholiogical } \\
\text { features }\end{array}$ & $\begin{array}{c}\text { GG frequency } \\
\boldsymbol{n}(\%)\end{array}$ & $\begin{array}{c}\boldsymbol{P} \\
\text { value }\end{array}$ & $\begin{array}{c}\text { CC frequency } \\
\boldsymbol{n}(\%)\end{array}$ & $\begin{array}{c}\boldsymbol{P} \text { value } \\
\text { WHO grade }\end{array}$ \\
I & $12(16.0)$ & $>0.05$ & $11(14.7)$ & $>0.05$ \\
II & $35(46.7)$ & & $35(56.2)$ & \\
III & $12(16.0)$ & & $13(17.8)$ & \\
IV & $16(21.3)$ & & $14(19.2)$ & \\
Age & & & & \\
$\geq 40$ & $36(48.0)$ & NS & $40(54.8)$ & NS \\
$<40$ & $39(52.0)$ & & $33(45.2)$ & \\
Gender & & & & \\
Male & $30(40.0)$ & NS & $31(42.5)$ & NS \\
Female & $45(60.0)$ & & $42(57.5)$ & \\
KPS & & & & \\
$\geq 70$ & $72(96.0)$ & $>0.05$ & $70(95.9)$ & $>0.05$ \\
$<70$ & $3(4.0)$ & & $3(4.1)$ & \\
\hline
\end{tabular}

NS not significant, KPS Karnofsky performance score.

unlikely to be of significance because they did not differ in the distributions of demographic variable and genotype frequencies. We limited all subjects' ethnicity to Han Chinese, and a living area to Xi'an City and its surrounding area, thus there is no substantial population admixture in our study populations.

In the upcoming studies, our team will go on to follow up the subjects recruited into the present study, and carry out additional research with larger subject numbers and grade types to further characterize the relationship among grades within the individuals, clinical features and the mentioned RTEL1 tagging SNPs \& haplotypes. Furthermore, to elucidate the role of the RTEL1 gene in gliomagenesis, serum RTEL1 expression levels between different mutations or haplotype groups will be compared. And, we will also investigate the association between germline RTEL1 variants and somatic RTEL1 mutations, and the relationship between serum RTEL1 expression and somatic RTEL1 expression in the same glioma subjects.

\section{Conclusion}

In conclusion, our comprehensive analysis of tSNPs suggests that the genotypes of "GG" of rs6010620 and "CC" of rs2297440 (rs6010620 and rs2297440) in the RTEL1 gene, together with two haplotypes of GCT and ATT, were identified to be associated with glioma development. And it might be used to evaluate the glioma development risks to screen the above RTEL1 tagging SNPs and haplotypes.

\section{Competing interests}

The authors declare that they have no competing interests.

\section{Authors' contributions}

CC and GG were the overall principle investigator of the study who designed the study and were responsible for study design, and interpreted the results. GL and TJ participated in the design and coordination, performed the molecular genetic evaluation, and drafted the manuscript. And ZZ, GC, HY, together with TG performed the statistical analysis, and joined into drafting the manuscript. All the patients were followed up by $Y T$, $\mathrm{SH}$ and $\mathrm{HL} . \mathrm{GL}, \mathrm{CC}$ and $\mathrm{GG}$ all contributed to improving the draft of the manuscript. All authors have read and approved the final manuscript.

\section{Acknowledgments}

This work is supported by grants from the National Natural Science Foundation of China (No. 81272776), China Postdoctoral Science Foundation funded projects (No. 20100471628 and No. 201104634), Wu Jieping Medical Foundation funded Project (320.6750.12161), Shaanxi Province Programs for Science and Technology Development (No. 2012 K 13-01-13 and 2011 K1247) and the Talents Program 2010, Tangdu hospital, the Fourth Military Medical University. We are grateful to all the patients and individuals for their participation. We would also like to thank the clinicians and other hospital staff who contributed to the blood sample and data collection for this study.

\section{Author details}

${ }^{1}$ Department of Neurosurgery, Tangdu hospital, the Fourth Military Medical University, Xi'an 710038, China. ${ }^{2}$ National Engineering Research Center for Miniaturized Detection Systems, School of Life Sciences, Northwest University, Xi'an 710069, China. ${ }^{3}$ Department of Clinical Experimental Surgery, Tangdu hospital, the Fourth Military Medical University, Xi'an 710038, China. ${ }^{4}$ Shaanxi Lifegen Co. Ltd, Xi'an 710069, China. ${ }^{5}$ Department of Radiology, Tangdu hospital, the Fourth Military Medical University, Xi'an 710038, China.

Received: 6 April 2013 Accepted: 12 May 2013

Published: 17 May 2013

\section{References}

1. Ostrom QT, Barnholtz-Sloan JS: Current state of our knowledge on brain tumor epidemiology. Curr Neurol Neurosci Rep 2011, 11:329-335.

2. Gigineishvili D, Shengelia N, Shalashvili G, Rohrmann S, Tsiskaridze A, Shakarishvili R: Primary brain tumour epidemiology in Georgia: first-year results of a population-based study. J Neurooncol 2013, 112:241-246.

3. Bondy ML, Scheurer ME, Malmer B, Barnholtz-Sloan JS, Davis FG, II'yasova D, Kruchko C, McCarthy BJ, Rajaraman P, Schwartzbaum JA, Sadetzki S, Schlehofer B, Tihan T, Wiemels JL, Wrensch M, Buffler PA: Brain tumor epidemiology: consensus from the Brain Tumor Epidemiology Consortium. Cancer 2008, 113:1953-1968.

4. Liu Y, Shete S, Hosking F, Robertson L, Houlston R, Bondy M: Genetic advances in glioma: susceptibility genes and networks. Curr Opin Genet Dev 2010, 20:239-244.

5. Wrensch M, Jenkins RB, Chang JS, Yeh RF, Xiao Y, Decker PA, Ballman KV, Berger M, Buckner JC, Chang S, Giannini C, Halder C, Kollmeyer TM, Kosel ML, LaChance DH, McCoy L, O'Neill BP, Patoka J, Pico AR, Prados M, Quesenberry C, Rice T, Rynearson AL, Smirnov I, Tihan T, Wiemels J, Yang P, Wiencke JK: Variants in the CDKN2B and RTEL1 regions are associated with high-grade glioma susceptibility. Nat Genet 2009, 41:905-908.

6. Shete S, Hosking FJ, Robertson LB, Dobbins SE, Sanson M, Malmer B, Simon M, Marie Y, Boisselier B, Delattre JY, Hoang-Xuan K, El Hallani S, Idbaih A, Zelenika D, Andersson U, Henriksson R, Bergenheim AT, Feychting M, Lönn S, Ahlbom A, Schramm J, Linnebank M, Hemminki K, Kumar R, Hepworth SJ, Price A, Armstrong G, Liu Y, Gu X, Yu R, Lau C, Schoemaker M, Muir K, Swerdlow A, Lathrop M, Bondy M, Houlston RS: Genome-wide association study identifies five susceptibility loci for glioma. Nat Genet 2009, 41:899-904.

7. Rajaraman P, Melin BS, Wang Z, McKean-Cowdin R, Michaud DS, Wang SS, Bondy M, Houlston R, Jenkins RB, Wrensch M, Yeager M, Ahlbom A, Albanes $D$, Andersson U, Freeman LE, Buring JE, Butler MA, Braganza M, Carreon T, Feychting M, Fleming SJ, Gapstur SM, Gaziano JM, Giles GG, Hallmans G, 
Henriksson R, Hoffman-Bolton J, Inskip PD, Johansen C, Kitahara CM, Lathrop M, Liu C, Le Marchand L, Linet MS, Lonn S, Peters U, Purdue MP, Rothman N, Ruder AM, Sanson M, Sesso HD, Severi G, Shu XO, Simon M, Stampfer M, Stevens VL, Visvanathan K, White E, Wolk A, Zeleniuch-Jacquotte A, Zheng W, Decker P, Enciso-Mora V, Fridley B, Gao YT, Kosel M, Lachance DH, Lau C, Rice T, Swerdlow A, Wiemels JL, Wiencke JK, Shete S, Xiang YB, Xiao Y, Hoover RN, Fraumeni JF Jr, Chatterjee N, Hartge P, Chanock SJ: Genomewide association study of glioma and meta-analysis. Hum Genet 2012, 131:1877-1888.

8. Chen H, Chen Y, Zhao Y, Fan W, Zhou K, Liu Y, Zhou L, Mao Y, Wei Q, Xu J, Lu D: Association of sequence variants on chromosomes 20, 11, and 5 (20q13.33, 11q23.3, and 5p15.33) with glioma susceptibility in a Chinese population. Am J Epidemiol 2011, 173:915-922.

9. Wang SS, Hartge P, Yeager M, Carreón T, Ruder AM, Linet M, Inskip PD, Black A, Hsing AW, Alavanja M, Beane-Freeman L, Safaiean M, Chanock SJ, Rajaraman P: Joint associations between genetic variants and reproductive factors in glioma risk among women. Am J Epidemiol 2011, 174:901-908.

10. Louis DN, Ohgaki H, Wiestler OD, Cavenee WK, Burger $P C$, Jouvet $A$, Scheithauer BW, Kleihues P: The 2007 WHO classification of tumours of the central nervous system. Acta Neuropathol 2007, 114:97-109.

11. Gabriel S, Ziaugra L, Tabbaa D: SNP genotyping using the Sequenom MassARRAY iPLEX platform. Curr Protoc Hum Genet 2009, 60:2.12.1-2.12.18.

12. Thomas RK, Baker AC, Debiasi RM, Winckler W, Laframboise T, Lin WM, Wang M, Feng W, Zander T, MacConaill L, Lee JC, Nicoletti R, Hatton C, Goyette M, Girard L, Majmudar K, Ziaugra L, Wong KK, Gabriel S, Beroukhim R, Peyton M, Barretina J, Dutt A, Emery C, Greulich H, Shah K, Sasaki H, Gazdar A, Minna J, Armstrong SA, Mellinghoff IK, Hodi FS, Dranoff G, Mischel PS, Cloughesy TF, Nelson SF, Liau LM, Mertz K, Rubin MA, Moch H, Loda M, Catalona W, Fletcher J, Signoretti S, Kaye F, Anderson KC, Demetri GD, Dummer R, Wagner S, Herlyn M, Sellers WR, Meyerson M, Garraway LA High-throughput oncogene mutation profiling in human cancer. Nat Genet 2007, 39:347-351.

13. Adamec C: Example of the use of the nonparametric test. Test $X 2$ for comparison of 2 independent examples. Cesk Zdrav 1964, 12:613-619.

14. Bland JM, Altman DG: Statistics notes. The odds ratio. BMJ 2000, 320:1468.

15. Purcell $S$, Neale B, Todd-Brown K, Thomas L, Ferreira MA, Bender D, Maller J, Sklar P, de Bakker PI, Daly MJ, Sham PC: PLINK: a tool set for wholegenome association and population-based linkage analyses. Am J Hum Genet 2007, 81:559-575.

16. Barrett JC, Fry B, Maller J, Daly MJ: Haploview: analysis and visualization of LD and haplotype maps. Bioinformatics 2005, 21:263-265.

17. Shi YY, He L: SHEsis, a powerful software platform for analyses of linkage disequilibrium, haplotype construction, and genetic association at polymorphism loci. Cell Res 2005, 15:97-98.

18. Wang L, Li PF, Geng M, Cao YC, Yin YC: Correlation between chemosensitivity to anticancer drugs and telomerase reverse transcriptase mRNA expression in gastric cancer. Diagn Pathol 2013, 8:33.

19. Lind-Landström T, Varughese RK, Sundstrøm S, Torp SH: Expression and clinical significance of the proliferation marker minichromosome maintenance protein $2(\mathrm{Mcm} 2)$ in diffuse astrocytomas WHO grade II. Diagn Pathol 2013, 8:67.

20. Wang Q, Deng J, Yuan J, Wang L, Zhao Z, He S, Zhang Y, Tu Y: Oncogenic reg IV is a novel prognostic marker for glioma patient survival. Diagn Pathol 2012, 7:69.

21. Gömöri E, Pál J, Kovács B, Dóczi T: Concurrent hypermethylation of DNMT1. MGMT and EGFR genes in progression of gliomas. Diagn Pathol 2012, 7:8.

22. Truong LN, Patil S, Martin SS, LeBlanc JF, Nanda A, Nordberg ML, Beckner ME: Rapid detection of high-level oncogene amplifications in ultrasonic surgical aspirations of brain tumors. Diagn Pathol 2012, 7:66.

23. Gulati S, Ytterhus B, Granli US, Gulati M, Lydersen S, Torp SH: Overexpression of c-erbB2 is a negative prognostic factor in anaplastic astrocytomas. Diagn Pathol 2010, 5:18.

24. Li G, Zhang ZG, Tu YY, Jin TB, Liang HJ, Cui GB, He SM, Gao GD: Correlation of microrna-372 upregulation with poor prognosis in human glioma. Diagn Pathol 2013, 8:1

25. Beuselinck B, Karadimou A, Lambrechts D, Claes B, Wolter P, Couchy G, Berkers J, Paridaens R, Schöffski P, Méjean A, Verkarre V, Lerut E, de la Taille A, Tourani JM, Bigot P, Linassier C, Négrier S, Berger J, Patard JJ, ZucmanRossi J, Oudard S: Single-nucleotide polymorphisms associated with outcome in metastatic renal cell carcinoma treated with sunitinib. Br J Cancer 2013, 108:887-900.

26. Pu X, Roth JA, Hildebrandt MA, Ye Y, Wei H, Minna JD, Lippman SM, Wu X: MicroRNA-related genetic variants associated with clinical outcomes in early-stage non-small cell lung cancer patients. Cancer Res 2013, 73:1867-1875

27. Peng J, Yang LX, Zhao XY, Gao ZQ, Yang J, Wu WT, Wang HJ, Wang JC, Qian J, Chen HY, Jin L, Bai CX, Han BH, Wang WM, Lu DR: VCP gene variation predicts outcome of advanced non-small-cell lung cancer platinum-based chemotherapy. Tumour Biol 2013, 34:953-961.

28. Barber LJ, Youds JL, Ward JD, Mcllwraith MJ, O'Neil NJ, Petalcorin MI, Martin JS, Collis SJ, Cantor SB, Auclair M, Tissenbaum H, West SC, Rose AM, Boulton SJ: RTEL1 maintains genomic stability by suppressing homologous recombination. Cell 2008, 135:261-271.

29. Uringa EJ, Lisaingo K, Pickett HA, Brind'Amour J, Rohde JH, Zelensky A, Essers J, Lansdorp PM: RTEL1 contributes to DNA replication and repair and telomere maintenance. Mol Biol Cell 2012, 23:2782-2792.

30. Youds JL, Mets DG, Mcllwraith MJ, Martin JS, Ward JD, ONeil NJ, Rose AM, West SC, Meyer BJ, Boulton SJ: RTEL-1 enforces meiotic crossover interference and homeostasis. Science 2010, 327:1254-1258.

31. Mirabello L, Yu K, Kraft P, De Vivo I, Hunter DJ, Prescott J, Wong JY, Chatterjee N, Hayes RB, Savage SA: The association of telomere length and genetic variation in telomere biology genes. Hum Mutat 2010, 31:1050-1058.

32. Uringa EJ, Youds JL, Lisaingo K, Lansdorp PM, Boulton SJ: RTEL1: an essential helicase for telomere maintenance and the regulation of homologous recombination. Nucleic Acids Res 2011, 39:1647-1655.

33. Adelman CA, Boulton SJ: Metabolism of postsynaptic recombination intermediates. FEBS Lett 2010, 584:3709-3716.

34. Simon M, Hosking FJ, Marie Y, Gousias K, Boisselier B, Carpentier C, Schramm J, Mokhtari K, Hoang-Xuan K, Idbaih A, Delattre JY, Lathrop M, Robertson LB, Houlston RS, Sanson M: Genetic risk profiles identify different molecular etiologies for glioma. Clin Cancer Res 2010, 16:5252-5259.

35. Bai C, Connolly B, Metzker ML, Hilliard CA, Liu X, Sandig V, Soderman A, Galloway SM, Liu Q, Austin CP, Caskey CT: Overexpression of M68/DcR3 in human gastrointestinal tract tumors independent of gene amplification and its location in a four-gene cluster. Proc Natl Acad Sci U S A 2000, 97:1230-1235.

36. Liu Y, Shete S, Etzel CJ, Scheurer M, Alexiou G, Armstrong G, Tsavachidis S, Liang FW, Gilbert M, Aldape K, Armstrong T, Houlston R, Hosking F, Robertson L, Xiao Y, Wiencke J, Wrensch M, Andersson U, Melin BS, Bondy M: Polymorphisms of LIG4, BTBD2, HMGA2, and RTEL1 genes involved in the double-strand break repair pathway predict glioblastoma survival. J Clin Oncol 2010, 28:2467-2474.

doi:10.1186/1746-1596-8-83

Cite this article as: Li et al:: RTEL1 tagging SNPs and haplotypes were associated with glioma development. Diagnostic Pathology 2013 8:83.

\section{Submit your next manuscript to BioMed Central and take full advantage of:}

- Convenient online submission

- Thorough peer review

- No space constraints or color figure charges

- Immediate publication on acceptance

- Inclusion in PubMed, CAS, Scopus and Google Scholar

- Research which is freely available for redistribution

Submit your manuscript at www.biomedcentral.com/submit

C) BioMed Central 